\title{
Risk among gastroenterologists of acquiring Helicobacter pylori infection: case-control study
}

\author{
Pius Hildebrand, Beat M Meyer-Wyss, Sandro Mossi, Christoph Beglinger
}

It has been suggested that endoscopists are at increased risk of Helicobacter pylori infection, but the results of the different studies have been contradictory. ${ }^{12}$ Part of the explanation for the controversy may be the fact that these were cross sectional epidemiological studies rather than prospective ones with long term follow up. The mode of transmission of $\mathrm{H}$ pylori infection is gastric/oral to oral or fecal to oral, and the human gastric mucosa serves as the main reservoir for the bacterium. As many patients undergoing endoscopy are positive for H pylori, gastroenterologists are likely to be exposed to infected saliva and gastric juice, and this could increase their risk of acquiring $H$ pylori infection.

This prospective study aimed to investigate whether gastroenterologists have a higher risk than a matched control group of acquiring $H$ pylori infection. In addition, we wished to determine whether wearing surgical gloves protects gastroenterologists from this infection.

\section{Participants, methods, and results}

Between 1989 and 1991, 92 gastroenterologists and 168 healthy control subjects matched for age and race were investigated by using a questionnaire and a ${ }^{13} \mathrm{C}$ urea breath test. The gastroenterologists were recruited during the annual meeting of the Swiss Society of Gastroenterology and Hepatology, while the control subjects were selected from participants in a large study of $H$ pylori prevalence. The cut-off value for the breath test was set at five parts per $1000 .{ }^{3}{ }^{4}$ Subjects who had taken antibiotics or proton pump inhibitor drugs within three months of testing were excluded. Altogether 56 gastroenterologists were negative and 36 were positive for $H$ pylori; 104 control subjects were negative and 64 were positive.

All subjects were white, and most were still living in the same area at the end of the observation period of five to eight years. In $1996-8$, the ${ }^{13} \mathrm{C}$ urea breath test was repeated in 54 of the 56 gastroenterologists who had previously been $H$ pylori negative (median age 47 (range 35-77) years) and in 103 of the 104 negative controls (49 (31-77) years) (table)

In 270 person years of follow up, seven gastroenterologists had acquired $H$ pylori infection (2.6\% per year); all seven wore gloves during endoscopy as a matter of routine. In the control group, only one subject became positive for $H$ pylori over 731 person years of observation $(0.14 \%$ per year). The difference in the per-

Seven year follow up of subjects who were negative for Helicobacter pylori at first testing

\begin{tabular}{lccc} 
Group & $\begin{array}{c}\text { H pylori } \\
\text { positive }\end{array}$ & $\begin{array}{c}\text { H pylori } \\
\text { negative }\end{array}$ & Total \\
\hline Control subjects & 1 & 102 & 103 \\
\hline Gastroenterologists* & 7 & 47 & 54 \\
\hline
\end{tabular}

*Pearson $\chi^{2}: \mathrm{P}=0.012$ (two tailed); Fisher's exact test: $\mathrm{P}=0.025$ (two tailed) compared with controls. centages of positive subjects in the two groups was $12.0 \%$ (95\% confidence interval $2.8 \%$ to $21.2 \%$ ). In the initial group of $H$ pylori positive gastroenterologists, 12 of 25 were negative on follow up testing. Although all newly negative gastroenterologists had completed various courses of treatment to eradicate the infection, only two would have qualified for treatment according to the criteria of the 1994 National Institutes of Health consensus conference. Despite these guidelines, many Swiss gastroenterologists with no symptoms underwent eradication treatment.

\section{Comment}

In a prospective, long term follow up study, we found that a group of gastroenterologists had a considerably higher risk of acquiring $H$ pylori infection than a matched control group. Although $H$ pylori infection seems to occur predominantly during childhood, ${ }^{5}$ it can be transmitted from infected patients to gastroenterologists when they perform endoscopies. Using surgical gloves did not protect against infection. The results suggest that oral infection via microscopic droplets of gastric juice produced by manipulating endoscopic instruments is the mode of transmission, but this remains to be proved. It would be interesting to determine whether wearing a facemask protects against $H$ pylori infection.

Contributors: $\mathrm{CB}$ and BMM-W had the idea for the study and the design. Data collection was performed by BMM-W, SM, and $\mathrm{PH}$. Analysis of breath tests was performed by PH, SM, and BMM-W. Statistical analysis was done by PH. The paper was written by $\mathrm{PH}$ and $\mathrm{CB} . \mathrm{CB}$ is the guarantor.

Funding: None.

Competing interests: None declared.

1 Mitchell HM, Lee A, Carrick J. Increased incidence of Campylobacter pylori infection in gastroenterologists: further evidence to support person-to-person transmission of C. pylori. Scand J Gastroenterol 1989;24:396-400

2 Braden B, Duan LP, Caspary WF, Lembcke B. Endoscopy is not a risk factor for Helicobacter pylori infection-but medical practice is. Gastrointest Endosc 1997;46:305-10.

3 Dill S, Payne-James JJ, Misiewicz JJ, Grimble GK, McSwiggan D, Pathak K, et al. Evaluation of ${ }^{13} \mathrm{C}$-urea breath test in the detection of Helicobacter pylori and in monitoring the effect of tripotassium dicitratobismuthate in non-ulcer dyspepsia. Gut 1990;31:1237-41.

4 Meyer-Wyss BM, Hildebrand P, Beglinger C. Breath tests: diagnostic studies. In: Browne TR, ed. Stable isotopes in pharmaceutical research. Amsterdam: Elsevier Science Publishers, 1997.

5 Megraud F. Epidemiology of Helicobacter pylori infection. Gastroenterol Clin North Am 1993;22:73-88.

(Accepted 25 April 2000)

\section{Endpiece \\ Elixir of life}

"The Elixir of Life?"

"Exactly. Think of people who have tried to find it."

"If I were to find such a thing I would throw it away."

T H White, The Once and Future King. London: Voyager, 1996.

\section{Department of Research, University Hospital, CH-4031 Basel, Switzerland Pius Hildebrand head of laboratory \\ Division of \\ Gastroenterology, University Hospital Sandro Mossi \\ consultant \\ Christoph Beglinger head \\ St Clara Hospital, Department of Internal Medicine, CH-4058 Basel, Switzerland Beat M Meyer-Wyss associate professor \\ Correspondence to: $P$ Hildebrand Pius.Hildebrand@ unibas.ch}

BMJ 2000;321:149 